\title{
ANALISA PERBANDINGAN KUALITAS BIODIESEL DARI MINYAK JELANTAH BERDASARKAN PERBEDAAN PENGGUNAAN JENIS REAKTOR
}

\author{
Muhammad Firdaus Jauhari ${ }^{(1)}$, Rusmini Sri Maryati ${ }^{(1)}$, Khairani ${ }^{(1)}$, \\ firdaus.jauhari@poliban.ac.id ,rusmini_sri42@yahoo.co.id, khairani@gmail.com \\ (1) Staf Pengajar Jurusan Teknik Mesin, Politeknik Negeri Banjarmasin
}

\begin{abstract}
Ringkasan
Penelitian ini bertujuan mengetahui proses pembuatan biodiesel dengan memanfaatkan limbah minyak jelantah serta mengetahui perbedaan penggunaan alat antara reaktor dan panci terhadap kualitas biodiesel. Saat ini ketersediaan minyak jelantah sangat banyak dan hanya dibuang tanpa dimanfaatkan. Minyak jelantah yang digunakan berasal dari limbah minyak goreng bekas minimal dua kali penggorengan.

Pembuatan biodiesel dari minyak jelantah dilakukan dengan proses transesterifikasi dengan dibantu katalis untuk mereaksikannya. Karena minyak jelantah yang dipakai sebagai penelitian hanya 2 kali penggorengan, maka kadar free fatty acids tersebut tidak banyak. Proses transesterifikasi dengan metanol memakai perbandingan antara sodium metoksida dan minyak jelantah. Waktu yang diperlukan untuk proses transesterifikasi adalah 60 menit dengan suhu konstan 65 OC. Alat pereaksi yang digunakan sebagai perbandingan yaitu antara reaktor labu leher tiga dengan panci stainless steel tertutup. Hasil penelitian menunjukkan bahwa tidak ada perbedaan yang nyata antara pembuatan biodiesel dengan menggunakan reaktor dengan menggunakan panci. Untuk hasil parameter biodiesel dengan menggunakan kedua alat tersebut juga tidak banyak berpengaruh terhadap kualitas biodiesel itu tersendiri.
\end{abstract}

Kata kunci: kualitas biodiesel, minyak jelantah, jenis reaktor.

\section{A. PENDAhULUAN}

Biodiesel umumnya diproduksi dari refined vegetable oil melalui proses transesterifikasi selain bahan bakar diesel dari minyak bumi. Biodiesel tersusun dari berbagai macam ester dan asam lemak yang dapat diproduksi dari minyak-minyak tumbuhan seperti minyak sawit (palm oil), minyak kelapa, minyak jarak pagar, minyak biji kapor randu dan minyak goreng.

Beberapa upaya telah dilakukan dalam penelitian dan pengembangan sumber energi alternatif diantaranya adalah pemanfaatan minyak nabati sebagai bahan pengganti solar, penggunaan secara langsung minyak nabati ini memiliki kekurangan yakni menghasilkan senyawa yang dapat menyebabkan kerusakan pada mesin karena membentuk deposit pada injector. Disamping itu viskositasnya yang tinggi mengganggu kinerja pompa injector pada proses pengkabutan sehingga hasil dari injeksi tidak berwujud kabut yang mudah menguap melainkan tetesan bahan bakar yang sulit terbakar. Oleh karena itu mesin - mesin kendaraan bermotor komersial perlu dimodifikasi jika akan menggunakan minyak nabati langsung sebagai pengganti bahan bakar solar. Hal ini tentu saja tidak ekonomis sehingga perlu dilakukan upaya untuk mengubah karakteristik minyak nabati agar sedapat mungkin menyerupai solar (BPPT, 2003)

Salah satu cara yang dapat dilakukan adalah dengan mengkonversi minyak nabati ke dalam bentuk metil ester asam lemak (FAME = Fatty Acid Methyl Ester) yang lebih dikenal sebagai biodiesel melalui proses esterifikasi atau transesterifikasi. Pada pengolahan biodiesel secara konvensional waktu pemanasan sangat berpengaruh pada capaian hasil esterefikasi.

Seiring dengan perkembangan populasi, tentunya limbah yang dihasilkan semakin banyak, termasuk minyak jelantah limbah industri dan rumah tangga. Minyak goreng dapat menyala pada suhu tertentu, hal ini berarti minyak goreng bisa digunakan sebagai bahan bakar alternatif khususnya pengganti solar. Namun jika menggunakan minyak goreng sebagai bahan baku tentunya harga penjualan biodesel akan lebih mahal daripada harga solar. Jika minyak goreng dapat digunakan sebagai bahan baku biodesel demikian pula halnya dengan minyak jelantah. Sebab minyak jelantah merupakan turunan terdekat dan memiliki sifat yang sama seperti minyak goreng. Tentunya solusi menjadikan minyak jelantah sebagai 
bahan bakar pengganti minyak solar akan dapat mengatasi dua masalah sekaligus yakni mengurangi limbah pencemaran lingkungan dan alternatif BBM khususnya solar. Sebab ketersediaan minyak bumi di dunia ini semakin menipis khususnya di Indonesia.

Pembuatan biodiesel dengan menggunakan minyak jelantah memiliki keunggulan dibandingkan solar. Namun yang menjadi permasalahan utama ialah pengumpulan minyak jelantah yang tidak mudah selain persebarannya cukup luas dan tidak merata. Disisi satu berdasarkan pengamatan penulis, para pedagang kecil yang menggunakan minyak goreng untuk dagangannya akan membuang minyak jelantah sisa penggorengan ke selokan yang terdekat yang bermuara pada sungai, sehingga dapat menjadi salah satu sumber polusi pada perairan sungai. Untuk itu perlu adanya dukungan dari pemerintah pusat maupun pemerintah daerah untuk penanganan limbah ini menjadi biodiesel, sebagaimana yang telah dilakukan oleh pemerintah kota Guangzhou, China. Guangzhou sebagai kota terbesar ketiga di China telah berhasil mengolah minyak jelantah sebanyak 20.000 ton pertahun untuk diolah menjadi biodiesel karena adanya dukungan dari pemerintah lokal (Y. Wang at al, 2007).

Menurut Evy : 2012, biodiesel dari minyak jelantah harus dianalisa terdahulu kadar asam lemak bebas (Free Fatty Acids), kadar air dan kotorannya serta dilakukan proses bleaching earth $1 \%$. Untuk proses penyaringannya menggunakan filter vacum pump. Pengolahan biodiesel menggunakan reaktor dilakukan dengan beberapa faktor yaitu dari proses penyaringan / filtrasi dengan filter paper $1 \mu \mathrm{m}$; $5 \mu \mathrm{m} ; 16 \mu \mathrm{m}$ dan proses pemanasan suhu sekitar $650 \mathrm{C}$ selaa waktu $30 ; 60$; 90 menit. Untuk meningkatkan kualitas bahan baku minyak jelantah digunakan teknologi mikrofiltrasi sehingga akan menurunkan kadar asam lemak bebas sebesar $13 \%-72 \%$. Jadi, karakteristik terbaik biodiesel minyak jelantah dicapai pada saat perlakuan filtrasi ukuran 16 $\mu \mathrm{m}$ dan lama proses transesterifikasi 60 menit.

Pada penelitian ini, penulis akan membuat biodiesel dengan proses yang sedikit berbeda dari penelitian (Evy, 2012) yaitu menggunakan reaktor dan panci. Penulis mencoba mencari apakah ada pengaruh perbedaan kualitas dan hasil terhadap penggunaan reaktor dan panci tersebut.

\section{B. LANDASAN TEORI}

Biodiesel (Methyl Ester) adalah bioenergi atau bahan bakar nabati yang dibuat dari minyak nabati, baik minyak baru maupun bekas penggorengan dan melalui proses transesterifkasi, esterifikasi, atau proses esterifikasi-transesterifikasi. Biodiesel dapat diaplikasikan baik dalam bentuk 100\% (B100) atau campuran dengan minyak solar pada tingkat konsentrasi tertentu (BXX), seperti 10\% biodiesel dicampur dengan $90 \%$ solar yang dikenal dengan nama B10 (Erliza, 2007 : 8).

Kepadatan volumetrik energi biodiesel sekitar $33 \mathrm{MJ} / \mathrm{L}$. Hal ini 9\% lebih rendah dari petrodiesel. Kepadatan energi biodiesel sangat bervariasi, dengan kecenderungan terhadap bahan baku yang digunakan daripada proses produksinya. Meskipun demikian, variasi jenis biodiesel lebih sedikit dibanding petrodiesel. Hal ini telah diklaim bahwa biodiesel memberikan pelumasan yang lebih baik dan memberikan pembakaran yang lebih sempurna sehingga dapat meningkatkan output energi mesin dan alternatif pengganti petrodiesel (Mukhibin, 2010 :28).

\section{Biodiesel dari minyak goreng bekas (Minyak Jelantah) \\ Biodiesel dapat dibuat dari minyak nabati,} lemak binatang, dan ganggang. Pemanfaatan minyak nabati sebagai bahan baku biodiesel memiliki beberapa kelebihan, diantaranya sumber minyak nabati mudah diperoleh dan tingkat konversi minyak nabati menjadi biodiesel tinggi (mencapai 95\%). Minyak nabati memiliki komposisi asam lemak berbeda - beda tergantung dari jenis tanamannya. Zat - zat penyusun utama minyak-lemak (nabati maupun hewani) adalah trigliserida, yaitu trimester gliserol dengan asam - asam lemak (C8 - C24). Komposisi asam lemak dalam minyak nabati menentukan sifat fisiko-kimia minyak.

Pengertian lain dari minyak jelantah adalah minyak yang dihasilkan dari sisa penggorengan, baik dari minyak kelapa maupun minyak sawit. Minyak jelantah dapat menyebabkan minyak berasap atau berbusa pada saat penggorengan, meninggalkan warna cokelat, serta flavor yang tidak disukai dari makanan yang digoreng.Dengan meningkatnya produksi dan konsumsi minyak goreng, ketersediaan minyak jelantah kian hari kian melimpah.

\section{Reaktor Biodiesel (Labu Leher Tiga)}

Reaktor adalah suatu alat proses terjadinya suatu reaksi berlangsung, baik itu reaksi kimia atau nuklir dan bukan secara fisika. Adanya reaksi inilah suatu bahan berubah ke bentuk bahan lainnya, perubahannya ada yang terjadi secara spontan atau terjadi dengan sendirinya dan bisa juga butuh bantuan energi seperti panas. Perubahan yang dimaksud adalah perubahan kimia, jadi terjadi perubahan 
bahan bukan fase misalnya dari air menjadi uap bukan merupakan reaksi kimia.

Ada dua jenis reaktor yaitu reaktor kimia dan reaktor nuklir. Kedua jenis reaktor berbeda dalam beberapa hal, pada reaktor kimia berlaku hukum kekekalan massa dikarenakan tidak ada massa yang hilang dalam reaksinya, tetapi hanya perubahan satu jenis zat ke jenis zat lainnya. Sedangkan reaktor nuklir tidak seperti itu, dalam reaktor ini ada massa yang hilang untuk diubah ke bentuk energi lain.

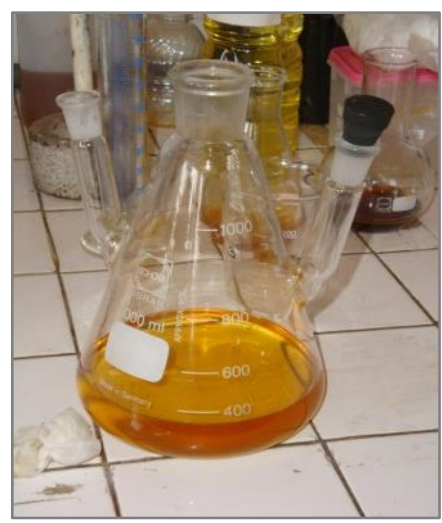

Gambar 1. Reaktor Biodiesel Sumber : Evy S (2012)

Konstruksi utama reaktor biodiesel dengan kapasitas daya tampung cairan adalah $1000 \mathrm{ml}$. Reaktor ini harus didesain tahan panas dan tidak cepat memuai, serta berbahan dasar kaca. Reaktor biodiesel memiliki tiga lubang untuk digunakan sebagaimana fungsinya. Lubang yang diatas dipergunakan sebagai wadah untuk meletakkan pendingin (kondensor). Sedangkan lubang yang berada dikiri dan di kanannya berfungsi untuk meletakkan thermometer dan tempat pencampuran sodium metoksida setelah minyak jelantah dipanaskan mencapai suhu didihnya.

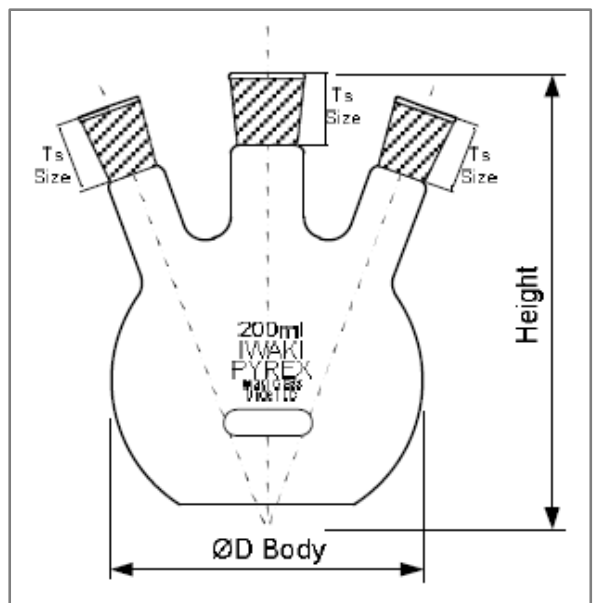

Gambar 2. Boiling Flask (Flask Bottom, 3 Neck) Sumber : Evy S (2012)
Pada prinsipnya, proses pembuatan biodiesel sangat sederhana. Biodiesel dihasilkan melalui proses transesterifikasi minyak atau lemak dengan alkohol. Alkohol akan menggantikan gugus alkohol pada struktur ester minyak dengan dibantu katalis. $\mathrm{NaOH}$ dan $\mathrm{KOH}$ adalah katalis yang umumnya digunakan (Erliza, $2007:$ 9).

Minyak/Lemak + Metanol/ $\begin{gathered}\text { Katalis } \\ \text { Etanol }\end{gathered} \begin{gathered}\text { Metil Ester/Etil Ester + Gliserin } \\ \text { (Biodiesel }\end{gathered}$

Biodiesel umumnya diproduksi dari refined vegetable oil (minyak murni) melalui proses transesterifikasi. Pada dasarnya, proses ini bertujuan untuk mengubah trigliserida menjadi asam lemak metil ester (FAME).

Kandungan asam lemak bebas (FFA) bahan baku merupakan salah satu faktor penentu jenis proses pembuatan biodiesel. Umumnya, minyak murni memiliki kadar FFA rendah (sekitar 2\%) sehingga dapat langsung diproses dengan metode transesterifikasi. Jika kadar FFA minyak tersebut masih tinggi, sebelumnya dilakukan proses pra-esterifikasi dengan menentukan terlebih dahulu harga FFA minyak (Erliza, 2007 : 9).

Proses pembuatan metil ester dari minyak nabati disebut transesterifikasi (transester-ifikasi). Transesterifikasi merupakan perubahan bentuk dari satu jenis ester menjadi bentuk ester yang lain. Proses transesterifikasi mereaksikan alkohol dengan minyak untuk memutuskan tiga rantai gugus ester dari setiap cabang trigliserida. Reaksi ini memerlukan panas dari katalis basa untuk mencapai derajat konversi tinggi dari minyak jelantah menjadi produk yang terdiri dari biodiesel dan gliserin (Jurnal Rekayasa Sriwijaya, 2008 : 17).

Secara umum, parameter standar mutu biodiesel terdiri atas densitas, titik nyala, angka setana, viskositas kinematik, abu sulfat, energi yang dihasilkan, bilangan iod, dan residu karbon. Beberapa Negara telah mempunyai standar mutu biodiesel yang berlaku di negaranya masing-masing. Adapun persyaratan mutu biodiesel Indonesia tercantum dalam RSNI EB 020551.

Dalam penelitian ini hanya menguji 6 dari 18 parameter standar mutu biodiesel Indonesia antara lain :

1. Viskositas Kinematik 400C

2. Titik Nyala (Flash point)

3. Angka Asam

4. Angka lodium

5. Gliserol Total

6. Kadar Ester 


\section{METODE PENELITIAN}

Penelitian ini dilakukan di Laboratorium Balai Riset Dan Standardisasi Industri (BARISTAND) Jalan Panglima Batur Barat No. 2 Banjarbaru.

Metode yang diterapkan pada penelitian ini adalah metode eksperimen, yaitu untuk menguji secara eksperimen perancangan percobaan berikut dengan membandingkan hasil pengujian biodiesel antara reaktor dan panci tertutup dengan menggunakan proses transesterifikasi.

Reaktor yang digunakan dalam penelitian ini adalah reaktor modifikasi labu, yang awalnya hanya menggunakan leher satu kemudian ditambah lagi (patri) lehernya menjadi tiga atau biasanya disebut labu leher tiga (boiling flask flatt bottom 3 neck). Fungsinya agar mempermudah pencampuran bahan kimia di dalam reaktor tersebut.Dan disitu juga tempat sirkulasi air pendingin (kondensor biodiesel).

Panci yang digunakan dalam penelitian ini adalah panci stainless steel merk Maspion $18 \mathrm{~cm}$. Panci ini memiliki penutup atas yang berfungsi untuk menutup bagian atas agar pada saat terjadinya reaksi transesterifikasi, metanolnya tidak menguap / berkurang. Karena apabila metanolnya menguap / berkurang itu akan mengakibatkan jeleknya kualitas dan hasil biodiesel yang diolah.

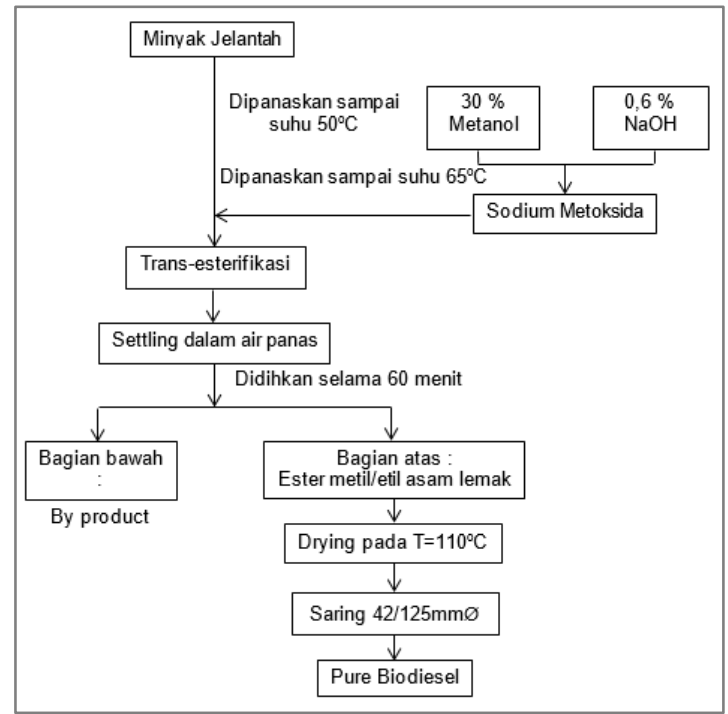

Gambar 3. Prosedur Pengujian Biodiesel Sumber : Evy S (2012)

\section{Transesterifikasi}

Pemanasan dan Pencampuran, pertama kali minyak jelantah dituang ke dalam reaktor dan panci tertutup, kemudian ditaruh di atas thermolyne untuk dipanaskan sampai mencapai suhu $500 \mathrm{C}$ (penulisan simbol derajat yang benar $50 \square \mathrm{C}$ ), untuk pemanasan awal. Pemanasan tersebut kira-kira selama $5-10$ menit tergantung dari penyetelan pemanasnya. Setelah suhu tersebut tercapai maka larutan sodium metoksid dituangkan ke dalam minyak jelantah sambil diaduk sampai kedua larutan tersebut menyatu sahingga secara kasat mata tidak terjadi pemisahan larutan antara minyak jelantah dengan sodium metoksid. Pemanasan dan pengadukan secara merata dilakukan pada suhu $650 \mathrm{C}$ selama 60 menit.

Pada saat larutan sodium metoksid dituang ke dalam minyak jelantah suhunya akan turun dari 500C menjadi sekitar 450C. Pada suhu ini dinaikkan sampai mencapai suhu $650 \mathrm{C}$ se hingga campuran kelihatan keruh. Pada proses ini terjadi reaksi pencampuran minyak dan methanol menjadi biodiesel dan gliserol dengan bantuan katalis $\mathrm{NaOH}$.

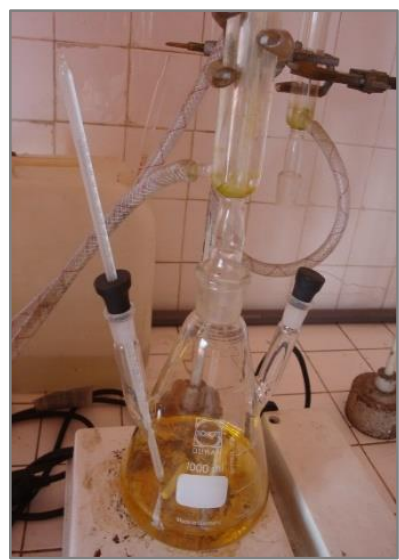

Gambar 4. Proses Transesterifikasi Sumber : Jauhari, MF (2012)

Prosedur Pengujian Titik Nyala (Flash Point) Metode Uji (ASTM D 93)

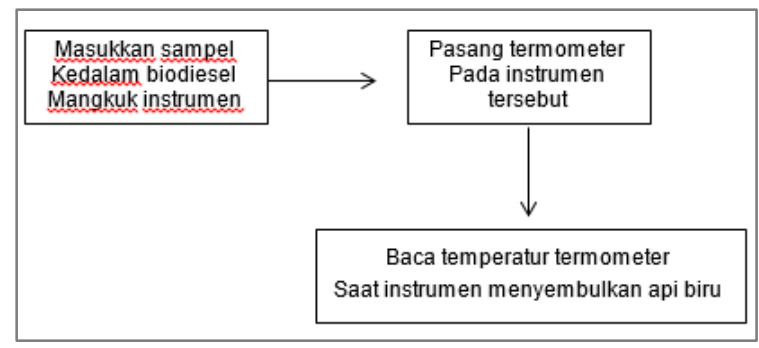

Gambar 5. Metode Uji ASTM D 93

Pengujian titik nyala biodiesel terbaca pada temperatur termometer pada saat menyemburkan api biru. 

uji ASTM D-664.

Prosedur Pengujian Angka Asam metode

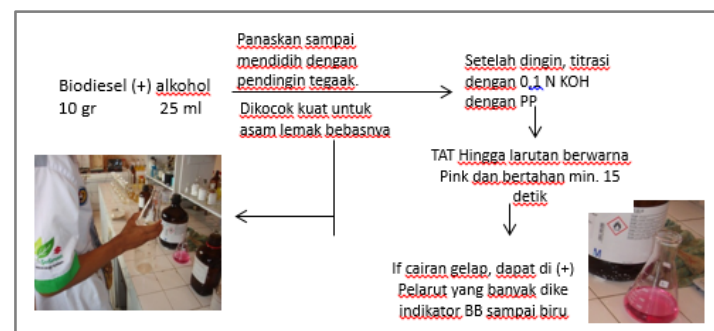

$\begin{gathered}\text { Angka Asam } \\ (\mathrm{Mg} \mathrm{KOH} / \text { Minyak) }\end{gathered}=\frac{m l \mathrm{KOH} \times \mathrm{N} \cdot \mathrm{KOH} \times 56,1}{w(g)}$

Gambar 6. Metode Uji ASTM D 664

Pengujian angka asam berdasarkan hasil miligram $\mathrm{KOH}$ terhadap massa biodiesel.

Prosedur Pengujian Viskositas Kinematik $40^{\circ} \mathrm{C}$ Metode Uji (ASTM D 455)

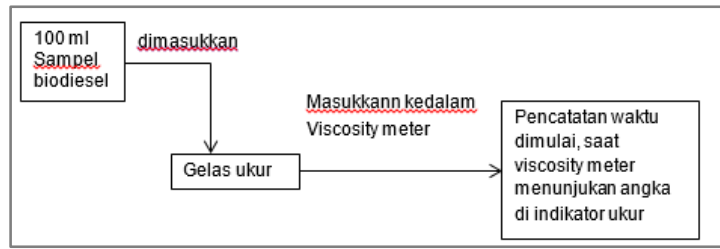

Gambar 7. Metode Uji ASTM D 455

Pengujian viskositas kinematik menggunakan viscosity meter untuk sampel $100 \mathrm{ml}$ biodiesel.

Prosedur Pengujian Gliserol Total Metode Uji (AOCS Ca 14-56)

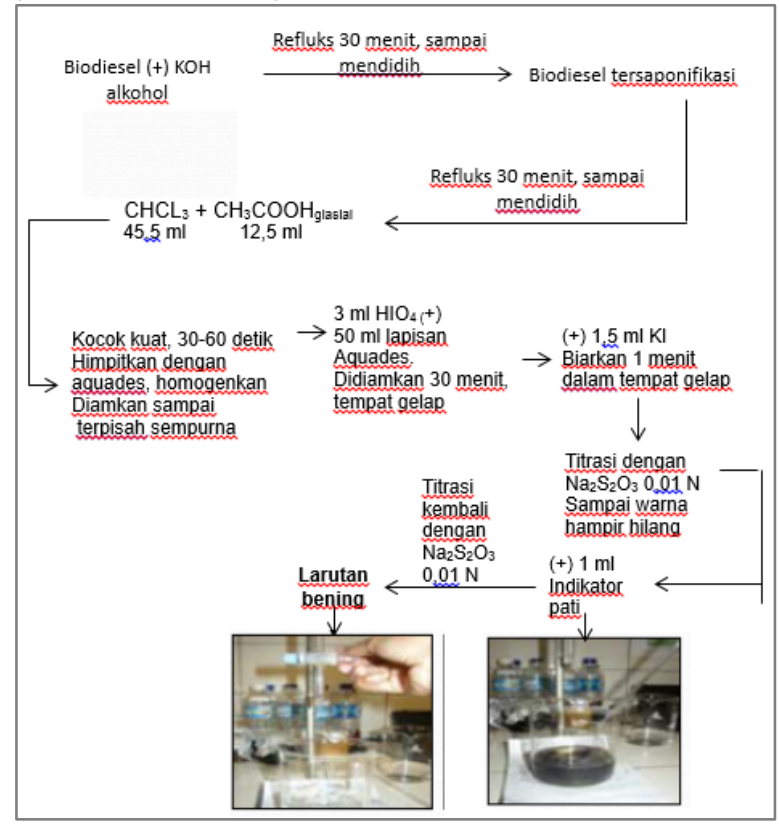

Gambar 8. Metode Uji Gliserol AOCS Ca 14-56
Pada pengujian gliserol total campuran biodiesel $+\mathrm{KOH}$ dilakukan refluks dan titrasi hingga menghasilkan larutan bening.

Prosedur Pengujian lodium Metode Uji (AOCS Ca 14-56)

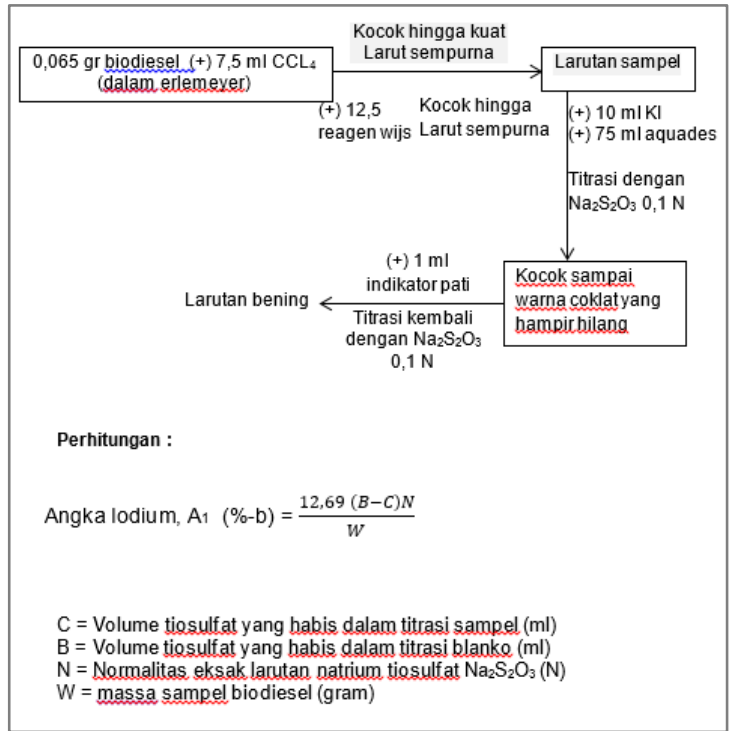

Gambar 9. Metode Uji lodium AOCS Ca 14-56

Pada pengujian lodium campuran biodiesel dan $\mathrm{CCl}_{4}$ di titrasi menggunakan $\mathrm{Na}_{2} \mathrm{~S}_{2} \mathrm{O}_{3}$ hingga menghasilkan larutan bening. Prosedur Pengujian Bilangan Penyabunan Dan Kadar Ester Metode Uji (FBI A03-03)

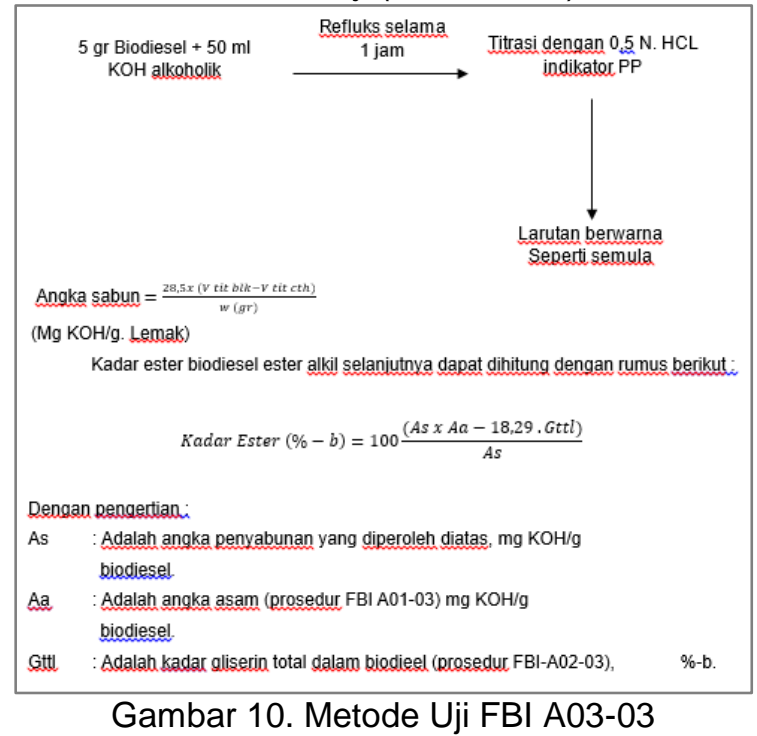

Pada pengujian kadar ester, campuran biodiesel dan $\mathrm{KOH}$ alkoholik direfluks dan dititrasi memakai larutan $\mathrm{HCl}$ hingga warna larutan kembali seperti semula. 


\section{Analisa Data}

Metil ester yang merupakan hasil atas reaksi dipisahkan dari gliserol pada lapisan bawah sampel. Sebelum di uji sifat fisisnya, metil ester ini perlu dimurnikan dengan cara mencucinya dengan aquades untuk mengikat gilserol dan metanol serta sabun yang masih tersisa. Dilanjutkan dengan proses destilasi, setelah terbentuk lapisan, kemudian dipisahkan.

Residu yang merupakan metil ester murni diuji sifat fisisnya dengan metode ASTM (American Society for Training and Materials) dilaboratorium Kimia, Baristand (Balai Riset dan Standardisasi Industri), kemudian hasil pengujian antara proses reaktor dan panci tertutup dibandingkan dengan spesifikasi SNI 04-7182-2006.

Tabel 1. Perbandingan Hasil Analisa dengan SNI menggunakan Reaktor dan panci tertutup

\begin{tabular}{|c|c|c|c|c|c|}
\hline \multirow{2}{*}{ No. } & \multirow{2}{*}{ Parameter yang diujii } & \multicolumn{2}{|c|}{ Rata-rata Hasil Renqujian } & \multirow{2}{*}{$\begin{array}{c}\text { SNI } \\
04-7182-2006\end{array}$} & \multirow{2}{*}{$\begin{array}{c}\text { Karakteristik } \\
\text { Solar }\end{array}$} \\
\hline & & Reaktor & $\begin{array}{l}\text { Panci } \\
\text { Tertutup }\end{array}$ & & \\
\hline 1 & Viskositas Kinematik $40^{\circ} \mathrm{C}$ & 2,67 & 2,73 & $2,3-6,0$ & $2,0-5,0$ \\
\hline 2 & Titik Nyala ${ }^{\circ} \mathrm{C}$ & 157,7 & 150,3 & Min. 100 & Min. 60 \\
\hline 3 & Angka Asam mg-KOH/g & 0,3 & 0,3 & Maks. 0,8 & Maks. 0,6 \\
\hline 4 & Angka lodium \%-b & 64 & 38 & Maks. 115 & - \\
\hline 5 & Gliserol Total \%-b & 0,16 & 0,14 & Maks. 0,24 & - \\
\hline 6 & Kadar Ester \%-b & 97,1 & 97,5 & Min. 96,5 & - \\
\hline
\end{tabular}

\section{HASIL DAN PEMBAHASAN}

\section{Viskositas Kinematik 40 OC}

Berikut ini merupakan hasil analisa viskositas kinematik $40^{\circ} \mathrm{C}$ dengan 3 kali pengulangan dengan alat uji yang berbeda ditabulasikan dalam bentuk tabel.

Tabel 4.2 Hasil Viskositas Kinematik $40^{\circ} \mathrm{C}$ Biodiesel

\begin{tabular}{|c|c|c|}
\hline \multirow{2}{*}{ Pengulangan } & Reaktor & Panci Tertutup \\
\hline & Viskositas Kinematik $40^{\circ} \mathrm{C}$ (CSt) & Viskositas Kinematik $40^{\circ} \mathrm{C}$ (CSt) \\
\hline 1 & 2,8 & 3,4 \\
\hline 2 & 2,0 & 2,4 \\
\hline 3 & 3,2 & 2,4 \\
\hline Rata-rata & 2,67 & 2,73 \\
\hline
\end{tabular}

Viskositas minyak diesel mempunyai nilai antara 2,3-6,0 cSt. Viskositas biodiesel yang dihasilkan mempunyai nilai diantara viskositas minyak diesel tersebut, sehingga jika ditinjau dari viskositas maka metil ester ini termasuk dalam standar sifat fisis bahan bakar diesel.

Viskositas bahan bakar minyak sangat penting artinya terutama bagi mesin-mesin diesel maupun ketel uap. Viskositas yang tinggi akan membuat bahan bakar teratomisasi menjadi tetesan yang lebih besar, dan memiliki kecenderungan bertumbukan dengan dinding silinder yang relatif lebih dingin. Sehingga bahan bakar tidak akan terbakar dalam waktu singkat dan produktifitas kerja mesin akan menurun.

Hal ini dapat mengakibatkan konsumsi bahan bakar meningkat. Sebaliknya, bila viskositasnya terlalu rendah maka harus menggunakan pelumas dengan viskositas cukup tinggi untuk melumasi bagian - bagian yang bergerak pada sistem bahan bakar dan membantu perapat (seal) bagian-bagian yang bergerak untuk mencegah kebocoran. Dengan viskositas rendah akan memproduksi spray yang terlalu halus dan tidak dapat masuk lebih jauh ke dalam silinder pembakaran sehingga terbentuk daerah fuel rich zone yang menyebabkan pembentukan jelaga.

Data analisa tersebut disajikan dalam bentuk grafik berikut.

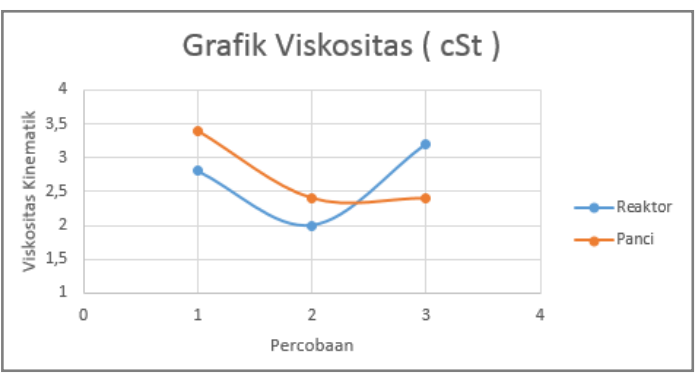

Gambar 11. Metode Perbandingan Viskositas Biodiesel terhadap reaktor dan panci tertutup

Dilihat dari data diatas viskositas yang dianalisa tidak memiliki perbedaan yang nyata dengan standar nasional Indonesia dari tiap alat uji yang digunakan

\section{Titik Nyala (flash point)}

Hasil pengujian flash point biodiesel minyak jelantah untuk berbagai perlakuan antara reaktor dan panci tertutup dapat diperlihatkan pada grafik berikut :

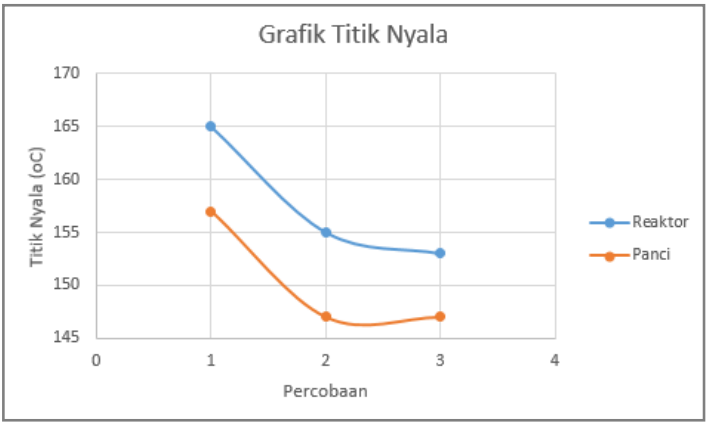

Gambar 12. Grafik nilai uji titik nyala terhadap penggunaan reaktor dan panci tertutup 
Grafik titik nyala terhadap proses pengolahan reaktor dan panci tertutup, grafik ini menunjukkan bahwa proses pengolahan antara rektor dan panci tertutup tidak mengalami perubahan yang nyata. Nilai standar flash point untuk biodiesel Indonesia sesuai SNI 7182:2015 minimum $100{ }^{\circ} \mathrm{C}$, sedangkan untuk solar maksimum $150^{\circ} \mathrm{C}$.

\section{Angka Asam}

Angka asam merupakan banyaknya miligram $\mathrm{KOH}$ yang dipakai untuk menetralkan kandungan asam lemak bebas dalam 1 gram biodiesel. Asam bebas ini terutama terdiri dari asam lemak bebas dan sisa asam mineral. Angka asam yang tinggi merupakan indikator biodiesel yang mengandung asam lemak bebas.

Angka asam menunjukkan jumlah asam mineral dan asam lemak bebas yang terkandung dalam sampel biodiesel. Dinyatakan dalam $\mathrm{mg}-\mathrm{KOH}$ dalam setiap $1 \mathrm{gr}$ biodiesel, dengan batasan maksimum $0,8 \mathrm{mg}-\mathrm{KOH} / \mathrm{gr}$ sample (sesuai SNI 04-7182-2006). Angka asam biodiesel tergantung berbagai faktor, misalnya jenis bahan baku proses dan proses pemurniannya. Selain itu, angka asam juga meningkat selama proses penyimpanan, hal ini berkaitan dengan proses hidrolitik ikatan ester, keasaman yang tinggi berhubungan dengan korosi dan pembentukan deposit pada mesin.

Kandungan asam lemak bebas yang tinggi dalam biodiesel sangat mempengaruhi kinerja mesin diesel, karena sifatnya yang korosif dan dapat menimbulkan jelaga atau kerak di injektor mesin diesel. Dari analisa yang dilakukan terhadap reaktor dan panci tertutup, didapatkan hasil sebagai berikut.

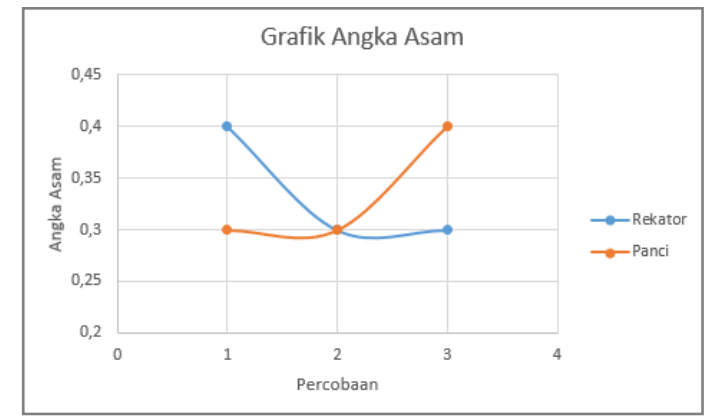

Gambar 13. Perbandingan Angka Asam Biodiesel terhadap reaktor dan panci tertutup

Hasil grafik menunjukkan bahwa tidak ada perbedaan yang nyata terhadap Standar Nasional Indonesia Biodiesel dengan menggunakan alat uji yang berbeda yaitu reaktor dan panci tertutup.

\section{Angka lodium}

Angka

iodium pada biodiesel menunjukkan tingkat ketidakjenuhan senyawa penyusun biodiesel. Di satu sisi, keberadaan senyawa lemak tak jenuh meningkatkan performansi biodiesel pada temperatur rendah, karena senyawa ini memiliki titik leleh (melting point) yang lebih rendah sehingga berkorelasi pada cloud dan pour point yang juga rendah. Namun di sisi lain, banyaknya senyawa lemak tak jenuh di dalam biodiesel memudahkan senyawa tersebut bereaksi dengan oksigen di atmosfer dan bisa terpolimerisasi membentuk material serupa plastik (Azam and Reihaneh, 2015). Oleh karena itu, terdapat batasan maksimal harga angka iodium yang diperbolehkan untuk biodiesel, yakni 115 berdasar standard Eropa (EN 14214). Di samping itu, konsentrasi asam linolenic dan asam yang memiliki 4 ikatan ganda masingmasing tidak boleh melebihi 12 dan $1 \%$.

Dari analisa yang dilakukan terhadap reaktor dan panci tertutup, didapatkan hasil sebagai berikut.

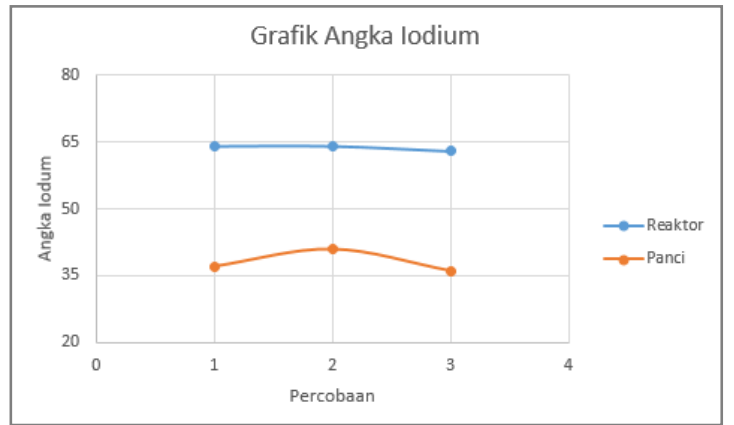

Gambar 14. Grafik Angka lodium terhadap perbandingan reaktor dan panci tertutup

Hasil grafik diatas menunjukkan bahwa tidak ada perbedaan yang nyata terhadap Standar Nasional Indonesia Biodiesel dengan menggunakan alat uji yang berbeda yaitu reaktor dan panci tertutup.

\section{Gliserol Total}

Dari hasil pengujian yang dilakukan terhadap biodiesel minyak jelantah dengan menggunakan reaktor dan panci tertutup diperoleh hasil pengujian gliserol total biodiesel minyak jelantah pada tabel berikut. 


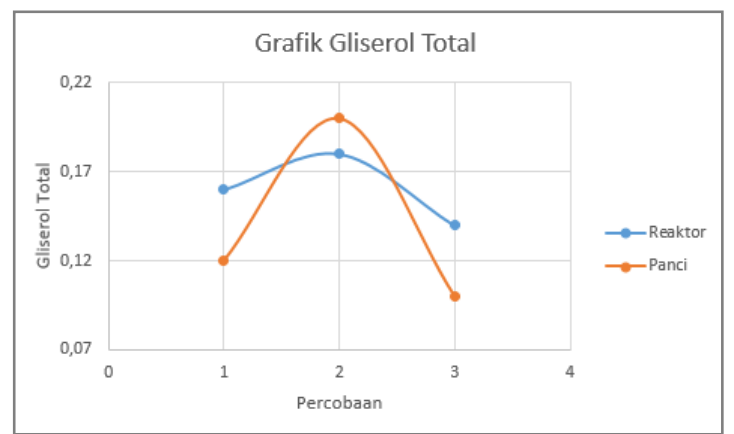

Gambar 15. Grafik gliserol total terhadap perbandingan reaktor dan panci tertutup

Biodiesel dengan 3 kali pengulangan memiliki kadar gliserol total yang berbeda, tetapi memenuhi standar nasional Indonesia biodiesel. Hal ini terjadi karena tidak adanya pengaruh dalam pembuatan biodiesel. Ini juga dikarenakan waktu yang tidak bervariasi dan suhu yang tidak bervariasi. Sehingga saat proses pengolahan biodiesel awal reaksi masih terdapat banyak trigliserida dalam minyak jelantah, yang belum terkonversi menjadi metil ester.

Hasil analisa diatas menunjukkan bahwa tidak ada perbedaan yang nyata terhadap Standar Nasional Indonesia Biodiesel dengan menggunakan alat uji yang berbeda yaitu reaktor dan panci tertutup.

\section{Kadar Ester}

Biodiesel yang dihasilkan berupa metil ester karena dalam reaksi transesterifikasi menggunakan metanol. Kadar metil ester tidak dapat langsung ditentukan, tapi dihitung melalui perolehan bilangan penyabunan, bilangan asam, dan kadar gliserol total sehingga analisis penentuan bilangan penyabunan juga dilakukan.

Dari hasil pengujian yang dilakukan terhadap biodiesel minyak jelantah dengan menggunakan reaktor dan panci tertutup diperoleh hasil pengujian kadar ester biodiesel minyak jelantah berikut.

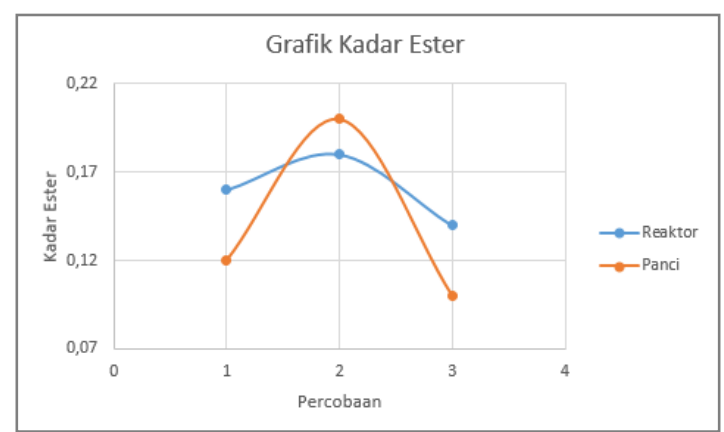

Gambar 16. Grafik Grafik kadar ester terhadap perbandingan reaktor dan panci tertutup
Pada grafik diatas dapat dilihat peningkatan kadar metil ester terjadi karena pengaruh alat uji. Tetapi untuk bisa dikatakan seperti itu harus dilakukan dengan beberapa faktor pendukung yaitu waktu dan suhu. Sedangkan untuk ini hanya menggunakan alat uji yang berbeda dan pada parameter uji tidak terjadi perbedaan yang nyata.

Jadi, hasil analisa diatas menunjukkan bahwa tidak ada perbedaan yang nyata terhadap Standar Nasional Indonesia Biodiesel dengan menggunakan alat uji yang berbeda yaitu reaktor dan panci tertutup.

\section{E. PENUTUP \\ Kesimpulan}

1. Biodiesel dapat dibuat oleh masyarakat umum karena hasil dari alat yang digunakan (panci tertutup), mempunyai kualitas yang tidak jauh berbeda dengan alat yang digunakan di laboratorium.

2. Pengolahan biodiesel dalam penelitian ini menggunakan dua alat yang berbeda yaitu reaktor dan panci tertutup, setelah dilakukan penelitian ternyata tidak ada perbedaan yang nyata dalam hal kualitas biodiesel itu sendiri.

\section{Saran}

1. Untuk mendapatkan hasil yang sangat akurat dalam hal pengujian parameter sebaiknya didukung dengan faktor faktornya seperti pengaruh waktu, pengaruh suhu dan jenis minyak yang digunakan

2. Dalam pengujian biodiesel dengan menggunakan perbandingan alat, tidak ada perbedaan yang signifikan maka ke depannya bisa dilakukan pengujian dengan metode lain untuk mendapatkan proses dan hasil biodiesel berkualitas tinggi.

\section{F. DAFTAR PUSTAKA}

1. Balai Rekayasa Desain dan Sistem Teknologi BPPT. Laporan Kegiatan Pengembangan Biodiesel Sebagai Energi Alternatif. 2003.

2. Evy S, Fatmir E. Teknologi Pengolahan Biodiesel Dari Minyak Goreng Bekas Dengan Teknik Mikrofiltrasi Dan Transesterifikasi Sebagai Alternatif Bahan Bakar Mesin Diesel. Jurnal Riset Industri Vol. VI No. 2. 2012.

3. Y. Wang, S. O. Pengzhan Liu, and Z. Zhang. Preparation of biodiesel from waste cooking oil via two-step catalyzed process. Energy Conversion and Management vol. 48, no. 1 , pp. 184-188, 2007

4. Erliza, dkk. Teknologi Bioenergi. PT. Agromedia Pustaka, Jakarta. 2007. 
5. Jurnal Rekayasa Sriwijaya. No.3. Vol.17. Nopember 2008.

6. Mukhibin. Mengubah Minyak Jelantah Menjadi Solar. Solomon. Yogyakarta. 2010.

7. Azam Jeihanipour and Reihaneh Bashiri. Perspective of Biofuels from Wastes. Biofuel and Biorefinery Technologies 1, DOI 10.1007/978-3-319-14033-9_2. 2015 